Review

\title{
Evolution of Smart Strategies and Machines Used for Conservative Management of Herbaceous and Horticultural Crops in the Mediterranean Basin: A Review
}

\author{
Sabina Failla ${ }^{1} \oplus$, Michel Pirchio ${ }^{2}, *$, Mino Sportelli ${ }^{2}$, Christian Frasconi ${ }^{2}$, Marco Fontanelli ${ }^{2}$, Michele Raffaelli $^{2}$ \\ and Andrea Peruzzi ${ }^{2}$ \\ 1 Section of Mechanics and Mechanization, Department of Agriculture, Food and Environment (Di3A), \\ University of Catania, Via Santa Sofia, 100, 95123 Catania, Italy; sfailla@unict.it \\ 2 Department of Agriculture, Food and Environment, University of Pisa, 56124 Pisa, Italy; \\ mino.sportelli@phd.unipi.it (M.S.); christian.frasconi@unipi.it (C.F.); marco.fontanelli@unipi.it (M.F.); \\ michele.raffaelli@unipi.it (M.R.); andrea.peruzzi@unipi.it (A.P.) \\ * Correspondence: michel.pirchio@for.unipi.it
}

Citation: Failla, S.; Pirchio, M.; Sportelli, M.; Frasconi, C.; Fontanelli, M.; Raffaelli, M.; Peruzzi, A.

Evolution of Smart Strategies and Machines Used for Conservative Management of Herbaceous and Horticultural Crops in the Mediterranean Basin: A Review. Agronomy 2021, 11, 106. https:// doi.org/10.3390/agronomy11010106

Received: 18 November 2020 Accepted: 30 December 2020 Published: 8 January 2021

Publisher's Note: MDPI stays neutral with regard to jurisdictional clai$\mathrm{ms}$ in published maps and institutional affiliations.

Copyright: (C) 2021 by the authors. Licensee MDPI, Basel, Switzerland. This article is an open access article distributed under the terms and conditions of the Creative Commons Attribution (CC BY) license (https:// creativecommons.org/licenses/by/ $4.0 /)$

\begin{abstract}
Preserving soil quality and increasing soil water availability is an important challenge to ensure food production for a growing global population. As demonstrated by several studies, conservative crop management, combined with soil cover and crop diversification, can significantly reduce soil and water losses. The aim of this review is to evaluate the spread of smart solutions to perform conservation agriculture (CA) well in the Mediterranean Basin, taking into account the evolution of the strategies and the machines used to perform conservative tillage systems in different contexts in the last 30 years, as well as the effects induced by their adoption on the productivity of herbaceous and horticultural crops, weed control and economic feasibility, in comparison with those obtained utilizing conventional techniques based on soil inversion.
\end{abstract}

Keywords: conservation agriculture; smart technologies; soil conservation; agricultural machinery; weed management; tillage; herbaceous and horticultural crops

\section{Introduction}

A vital part of humanity's global life support system consists of both agricultural and non-agricultural soils. Countering the multiple threats to which soil is exposed (desertification, erosion, reduction of organic matter, compaction, waterproofing, contamination, salinization, flooding and landslides) is a shared commitment at international level. It was explicitly foreseen by the agreements of the 1992 Rio de Janeiro summit and by those of the following years, but it is also mentioned among the United Nations Sustainable Development Goals of 2015 [1]. In this respect, In September 2015 more than 150 international leaders met at the United Nations to contribute to global development, promoting human welfare and protect the environment. The community of states has adopted Agenda 2030 to sustainable development, promoting 17 Sustainable Development Goals (SDGs) and 169 sub-goals. These goals take up issues of fundamental importance for sustainable development such as tackling climate change and building peaceful societies by the year 2030. All countries should contribute to achieve the goals based on their capacity. As is the case with other natural resources, soils are subjected to a dangerous pressure that leads to consequent organic carbon losses, salinization, compaction and erosion [2]. Moreover, soil resources degradation negatively affects environmental, economic and social aspects at various intensities. In fact, soil is a non-renewable resource, and must be preserved for the well-being of our planet as it is exposed to the risk of very rapid degradation processes but has very long regeneration times. The need to preserve soil resources and to maintain the functionality of its numerous ecosystem services is also recognized by the European Union (EU), as the effects linked to the increase in soil degradation are also manifested 
to significant areas in Europe, although with some diversification among the different countries [3,4]. Consistent with the principles of efficient growth in the use of resources, therefore, the EU promotes effective initiatives to reduce erosion and increase the amount of soil organic matter [5]. The EU also reiterates the need to contain the soil degradation in the 7th General Program of Action on the Environment until 2020. In agricultural contexts, these significant threats are often correlated to soil tillage intensity. Indeed, intensive agriculture, characterized by conventional tillage, consisting in interventions at relevant soil depth always including soil inversion (i.e., ploughing, digging, etc.), is connected with high input levels, has negative impacts such as water loss, freshwater pollution due to nitrate leaching, biodiversity fade and soil erosion increase [6]. Conservation agriculture (CA) could be considered as an important part of integrated soil management and has shown to be a valid technique to prevent all types of soil erosion [7]. One of the main targets of CA is the limited use of soil tillage without soil inversion, since it can contribute to improving soil conditions and the efficient use of water resources and nutrients [8]. In addition to reduced soil disturbance, according to intrinsic soil conditions and relative availability of water resources, CA also provides for maintenance of organic substance, through the occurrence of crop residues, cover crops and also crop rotation with at least three different crops [9]. CA joins the largely accepted concepts of sustainability both in terms of environment and socio-economic features. Sustainable soil management not only is coherent with the indications of CA, but also shows the need to counteract negative externalities and degradation phenomena of soil. These are shown with different intensities in many areas of the world, with the aim of reaching land degradation neutrality and containing the rise of the average temperature of the atmosphere at $1.5^{\circ} \mathrm{C}$ by $2030[10,11]$. The need of soil safeguarding is strategic for several independent reasons: food production, water availability, biodiversity maintenance, organic matter increase, carbon sequestration, and improvement of environmental resilience contrasting climatic changes. At global level, soil degradation causes a loss of up to $50,000 \mathrm{~km}^{2}$ year ${ }^{-1}$ of arable land, with a reduction of soil of about 24 billion $t$ year $^{-1}$ [12]. Furthermore, soil degradation induced by human activities increases global warming and would be responsible for about one fifth of carbon emissions into the atmosphere from 1850 to 1998 [13]. CA represents an efficient alternative capable of improving a sustainable agro-ecological approach to resource-conserving agricultural production. As stated by Sims et al. [14], CA is a response to sustainable land management, environmental protection and climate change adaptation and mitigation. Baker et al. [15] defined conservation tillage and conservation agriculture as terms commonly given to no-tillage, minimum tillage and/or ridge tillage, denoting that these inclusive practices have a conservation goal of some nature. Usually, the retention of at least $30 \%$ ground cover by residues after seeding or planting characterizes the lower limit of classification for conservation tillage or conservation agriculture, but other conservation objectives include conservation of money, labour, time, fuel, earthworms, soil water, soil structure and nutrients. Thus, residue levels alone do not adequately describe all conservation tillage or conservation agricultural practices and benefits. Moreover, CA systems, comprising no or minimum mechanical soil disturbance, organic mulch soil cover and crop species diversification, are practiced globally on about $157 \mathrm{M}$ ha, corresponding to about $11 \%$ of field cropland, and Europe and Africa are the developing continents in terms of CA adoption and uptake [16]. Other authors argue that the tendency of CA in preserving the environment (including the reduction of soil erosion) and improving soil properties cannot be underestimated $[17,18]$. The potential of CA to mitigate the effects of climate changes and extreme weather events was highlighted also by De Lucas et al. [19] and Deligios et al. [20]. However, despite these positive effects, soil conservation practices are not always adopted although the spreading of CA is often correlated to an economic incentive for the farmer [2]. In Europe the acceptance of conservation tillage is quite slow because the culture of soil conventional and soil inversion tillage is often deeply rooted among many farmers [21]. Moreover, as stated by Acevedo [22], farmers tend to adopt practices that produce tangible results rather than practices that may lead to improvements of a more 
abstract environmental nature, such as biodiversity. The challenge could be to develop adoptable innovations that help environmental conservation while representing a tangible advantage for the farmers. Furthermore, the reduction of crop yields if no additional inputs are provided and the increase of machinery and agrochemicals costs, that overcomes savings in fuel and labour costs, are another reason for the slow adoption of CA practices. In the temperate zone of large-scale mechanised agriculture, the direct benefits of the implementation of conservation agriculture and/or other soil conservation measures are often marginal to justify a real change of a single farmer. The local agro-ecological system could be able to stimulate a more rapid adoption of soil conservation measures even if the studies reported by some authors indicate that there are few influences on its adoption that can be applied universally [6]. Smallholder agriculture in North-African countries does not have access to agricultural credit and has a limited technical know-how. In farming areas that lack water, holistic interventions performed by CA practices can promote a safe environment with zero environmental and human hazards. This latter is regarded as a "panacea" to achieve food security and the requested optimal performance in agricultural production [18]. Current threats require advanced analysis of best-fit solutions for agricultural technologies to serve also smallholder farmers' needs. Climate smart agriculture (CSA) defined as agricultural practices that sustainably improve production, resilience of production systems, and reduce greenhouse gas emissions is required to overcome climate extremes and variability [23]. Smart agricultural technologies are essential to advance the development, productivity, and sustainability of the crops and several steps have been taken to deploy novel agricultural technologies to farmers also by agricultural enterprises. During the past three decades, there has been an increasing cognisance that technologies need to be fitted to the environmental conditions of farmers including sustainability goals and reduction of climate changes. Although not having a unique policy of soil protection, the EU has been committed to defining a thematic strategy for soil protection since 2002 [24]. The attention placed by the European Union has significantly increased over the last few years and with the 2003 reform, conditionality measures assume a key role together with the Good Agronomic and Environmental Practices (BCAAs), established by the individual member states under the Common Agricultural Policy (CAP). The BCAAs aim to limit the erosive phenomena affecting agricultural soils, improve organic matter in soils and prevent compaction phenomena. Within the CAP, in addition to the agri-environmental measures, the EU has recognized the possibility to exclude ploughing of agricultural land, among the interventions aimed at reducing tillage. The objective of the strategy is soil protection through a sustainable use able to guarantee the fulfilling of various functions of which the environmental, social, economic and cultural values are recognized. In particular, the interventions aim at mitigating both the natural soil degradation processes and those due to human activities. However, the lack of a common strategic political framework, capable of integrating and coordinating the various European and national legislative initiatives, limits the effectiveness of the numerous interventions for soil protection promoted by the EU and by member states [25]. Therefore, one of the most effective tools for sustainable soil management in Europe is represented by the CAP [26]. The objective of improving soil management in the context of the CAP has been further supported over the past few years, combining soil conservation measures with those of conservation agriculture, which constitute an element of further interest in view of the CAP post 2020. Furthermore, the inclusion of greenhouse gas emissions and absorptions caused by land use and land-use change and forestry are the specific topic in the EU 2030 climate and energy framework, which aims to enhance actions targeted at sustainable soil management also taking into consideration the soil tillage [27]. Currently, the sustainable use of soil is covered in some measures foreseen by the rural development programs for the 2014-2020 period and mainly under measure 10. This measure concerns agro-climate environmental payments, with which agricultural farms are encouraged to adopt environmentally sustainable actions and cultivation interventions. Among these actions are also recognized those related to soil tillage management, not only in relation to the control of erosion phenomena, but also 
in relation to the practices aimed at reducing compaction risks, improving soil structure. Thus, the conservation and low input practices in energy terms, including sod-seeding, minimum tillage and cover cropping, became practices able to obtain direct and indirect positive effects on sustainable soil management. The conservation and low input practices improve soil quality, increase organic matter and reduce the risks of soil erosion [28]. The purpose of this review is to verify the spread of smart solutions to perform CA well in the Mediterranean Basin, the evolution of the techniques and the machines used and their setting up as well as the results achieved in different contexts and the effects induced on soil quality and on the productivity of different herbaceous and horticultural crops. Finally, the examination of some aspects related to the economic feasibility of the adoption of machines and strategies for CA could lead to the definition of a broad knowledge framework, useful to supporting and directing lawmakers' choices.

\section{Smart Strategies and Innovative Agricultural Machinery for a Conservation Management of Herbaceous and Horticultural Crops}

\subsection{From Conservation Agriculture to Precision Conservation Management}

As already presented in the previous paragraph, CA is based on the integrated management of soil, water and agricultural resources in order to reach a sustainable agricultural production in ecological, economical, and social terms. Despite some resistance concerning the management aspects (i.e., weed control) and absence of adequate drills, planters and transplanters, the adoption of conservation practices represents great potential for herbaceous and horticultural crops. The adoption of "recommended agricultural practices" is a solution to the environmental issues and to achieve global food security [29]. Such practices would include use of conservation tillage, growing cover crops, using bio-solids and amendments, enhancing soil fertility through judicious use of fertilizers and adopting precision farming and water conservation. Over the years the concept of CA has assumed connotations progressively more linked to the concept of precision CA and to new technologies aimed at performing specific agronomic practices, considering the real needs of crops. Berry et al. [30] proposed "Precision Conservation Management Zones" like a viable combination of site-specific management zones and precision conservation management zones in order to maximize resource use efficiency, soil and water conservation and economic returns. The authors referred to a significant maximisation of $\mathrm{N}$ efficiency of corn crops without reducing grain yield and minimisation of $\mathrm{NO}_{3}-\mathrm{N}$ leaching and offsite transport of $\mathrm{N}$ by means of the use of the Global Navigation Satellite System (GNSS), remote sensing and geographic information systems (GIS) tools. Moreover, precision conservation management will benefit from novel advances in the areas of telecommunications and micro-technology that can contribute to enhance real-time information. A few years later, other studies [31-33] have expanded the definition of precision conservation to a developing science based on the new geospatial technology (i.e., map analysis, spatial statistics, surface modelling, spatial data mining). These technologies allow to link a system from a site-specific location to a field, a set of fields (farm), or a regional scale in order to identify landscape risk areas, make management decisions, implement conservation practices and enhance crop production. In this regard, some studies carried out in NE Italy have investigated farm economic net return and environmental aspect [34] of three different conservation tillage practices (NIT—non-inversion tillage, MT—minimum tillage and NT-no-tillage). These operations were performed at variable intensity within predefined two management zones of a maize field in NE Italy: an area with a consistently higher yield and another one with a consistently lower yield. The overall results suggest that NT, employing a double-disk no-till planter, resulted in being a method with a lower environmental impact due to higher soil carbon sequestration and lower nitrate leaching. Moreover, the adoption of site-specific NT within the two different areas was more economically sound than all other tillage practices uniformly performed in the field. Nevertheless, claims of increased profitability from measuring, mapping, and site-specific management have in many instances fallen short, conditioning farmers to be more sceptical of precision agriculture. By contrast, Kitchen [35] demonstrated that the use of computers and sensors 
for real-time decisions in cropping systems could represent a new way of agricultural management to achieve conservation and other environmental benefits. As an example, the sensor system could predict about $66 \%$ of the variation in soil organic matter within fields but also a side-by-side field assessment of two on-the-go soil compaction sensor systems could be capable of sensing compaction at various soil depths.

\subsection{Tillage and Planting}

Soil tillage is a crucial aspect in CA crop management and the latter can be realised with three main soil management practices related to NT, MT and ridge tillage (RT) techniques [17]. While NT (also called zero-tillage) management practices are well defined, the definition of MT (also named reduced tillage) represents a remarkable variety of machines and operative solutions, which also prevent an unambiguous evaluation on their efficacy in realising the agro-environmental advantages of the CA. With this aim, in Italy, a study of Lovarelli and Bacenetti [36] showed that seedbed preparation for arable crops completed with two implements (one for primary and one for secondary soil tillage) instead of three (e.g., one for primary and two for secondary soil tillage) resulted in a reduction of environmental impact. The best results were obtained with low energy-consumptive operations as MT practices, whereas the main contributor to the environmental load was the use of a subsoiler before seedbed preparation. But more in general, as is well known, they demonstrated that environmental burden is principally due to the number of repetitions of secondary soil tillage. In this context, the CA practices (e.g., NT, MT) represent a solution also to preserve natural resources and reduce environmental and economic costs of agricultural activities.

No-tillage (NT) is just one of the principles of CA and is based on the achievement of a new balance between physical, chemical and biological soil elements. It was developed in the second post-war period, with the introduction of weed control by means of glyphosate. It provides for sowing directly on crop residues of the previous crop left on the soil. Therefore, this technique provides suitable seed drills, planters and transplanters capable of depositing the seeds and covering them in conditions of no tilled soil, so realizing a direct seeding/planting also called sod seeding, in which usually 30-100\% of the surface remains covered with plant residues $[37,38]$. Although some researchers have emphasized differences in soil disturbance between NT and direct drilling, the latter term commonly includes the sod-seeding practice which is a typical sowing of NT practices [39]. NT plays a key role in CA systems and NT research is still active in several countries of Europe and there has also been an increasing attention to suitable machines for these practices. According to a recent study [40], there are 46 planters intended for NT management having a working width ranged from 1.2 to $6.5 \mathrm{~m}$, a mass between 1200 to $9000 \mathrm{~kg}$. There is a great variability of these seeding machines because the available models have different designs of the soil-engaged working elements (furrow). In comparison with other types of seeder, they involve greater economic investments. Yezekyan et al. [40] showed that planting implicates more pressure on the furrows if there is a presence of residues, meaning a higher effort for the machine itself and a minimum required power ranging from $5.9 \mathrm{~kW}$ to $21.5 \mathrm{~kW}$ for each meter of working width. Working width plays a significant direct role on no-tillage machines performances. To reduce the residual interference towards sowing, weeding, nitrogen nutrition and the control of plant and animal parasites, crop residue management is an aspect of fundamental importance in conservation tillage and especially in NT practices. For this reason, it requires specific skills and the use of adequate machines as well as adequate machines. The setting and adjustment of seed drills, precision planters and transplanters play a decisive role in ensuring the efficiency of sowing. Moreover, the choice of the right set of components, the adjustment of the loading pressure and the working depth are aspects to be considered according to specific pedological conditions and characteristics of the crop residues [16]. Sometimes, drilling and planting may be the key limitation to change to no-tillage farming $[39,41]$. Modifying drills, planters and transplanters used in conventional tillage farming has generally not been very successful and in 
the worst case it was very ineffective and stimulated weed growth. Planting depth can be difficult to manage because of the machine's increased weight and the opening generated by the fluted cutting disc [42]. No-till drills and planters equipped with rubber ground wheels that allow adjustment of height and depth bands on the coulter and " $\mathrm{V}$ " openers can also help to reduce planting depth difficulties using precision agriculture technologies. In order to maximise potential yield, seed placement close to ideal sowing depth must be assured [15,43]; but seed placement accuracy is especially critical with no-till sowing into dry soil [44]. This is linked to the negative relationship between soil mechanical resistance and seed depth placement; but also, penetration resistance is lowest with very wet soils and it increases with clay content [43]. In particular, the performance of seeders and planters should be improved by getting better calibration systems for depth control or precision regulation by the worker, in relation to field conditions. Several studies were carried out to assess the performance of furrow openers, which can differ in type, correlating to soil and working conditions. Single-disc furrow openers (ballasted, notched, flat or wavy type) are generally used on no-till seeders because they enter properly into the soil and have suitable cutting of residues under different residue and soil conditions (Figure 1).

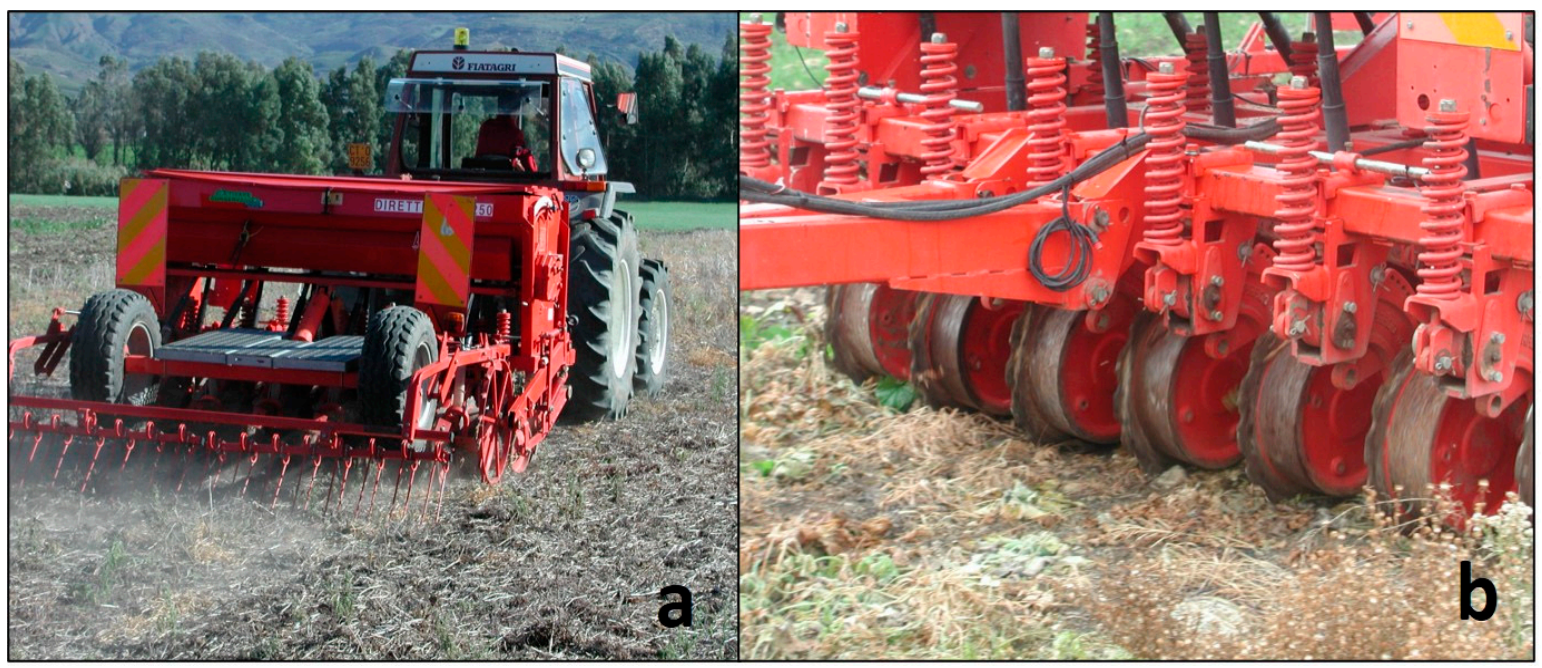

Figure 1. No-tillage (NT) drill Directa $2.5 \mathrm{~m}$ wide at work in Sicily on soil covered by chopped crop residues (a) and detail of the working tools constituted by ballasted discs $(\mathbf{b})$.

As already demonstrated, disc and tilt angles are the most important parameters for the performance of furrow openers on residues and soil [45-48]. Afify et al. [45] showed that the best results for a $610 \mathrm{~mm}$ disc diameter were obtained at $5^{\circ}$ and $15^{\circ}$ angles, while a $460 \mathrm{~mm}$ disc diameter had the lowest draft at a $5^{\circ}$ tilt angle and $25^{\circ}$ disc angle, in an indoor soil bin experimental test. Moreover, Malasli and Celik [48] reported that a rise in disc angle from $0^{\circ}$ to $20^{\circ}$ reduces draft, side and vertical forces, i.e., an increasing tilt angle causes the specific vertical, draft and side forces to grow. The $7.5^{\circ}$ and $10^{\circ}$ tilt angles mostly offer better results than $5^{\circ}, 2.5^{\circ}$ and $0^{\circ}$. Other studies demonstrated that a more vertical load for single and double-disc furrow openers in pneumatic seed drills used for NT practices in two different field conditions (clay-loam and loamy soil) leads to enhanced machine performance in Turkey. In particular, planting depth and seed spacing uniformity, mean emergence time and percentage of emergence of both furrow openers were increased by increasing down-force [47]. As concerns the type of furrow opener, no-till seeders with hoe-type gave better sowing performance and seed emergence in comparison to the no-till seeders with disc- and wing hoe type furrow openers under $12 \mathrm{~cm}$ (short) stubble of common vetch and standing stubble conditions in Turkey [49]. As highlighted before, maintenance of residue cover on the surface is a fundamental requirement for CA aims. In this regard, a recent review on performances of different residue management units of NT sowing systems confirmed that smooth disc coulters, finger row cleaners, 
and their combinations can retain more than the minimum residue cover recommended for NT systems. Moreover, the selection of the appropriate residue management units and machinery settings reduces blockage and allows for correct placement of seed and improved seed-soil contact [50]. Nowadays, drill and planter development has progressed to supply acceptable seed placement into the soil in many different conditions, both for row and precision sowing. New technologies are now proposed as optional equipment to improve machines performances, as satellite systems (Global Navigation Satellite System), seed counting devices, integrated infrared sensors, down force controllers [40], but their spreading in the Mediterranean areas is still very slow. In Italy, actually NT is not a common practice in horticulture because of low yields that are commonly associated with soil compaction, reduced nitrogen availability and high weed encroachment. During the last few years, specific transplanters have been designed and built in order to assure an appropriate furrow opening, plant deposition and furrow closure with the right soil compaction. However, most no-till transplanters have been developed as prototypes and have been tested only by researchers [42,51-53]. Thus, these machines are not available on the market for farmers [42]. One of the first trials on NT transplanters was carried out by Morse et al., [54] using a subsurface tiller-transplanter (SSS-T) developed by B\&B No-Till (Laurel Fork, VA), in collaboration with Virginia Polytechnic Institute. Although this prototype was designed and realized in the Mediterranean Basin, it is necessary to describe this machine, as it was the first prototype of NT transplanter realized. The SSS-T consists of two components and combines subsurface soil loosening and transplanting. This allows soil compaction to be reduced and transplantation in a single operation. The SSS-T has a single subsurface tiller placed in front of a double disk shoe to operate with low soil disturbance in conditions of high surface residues [54]. Frasconi et al., [42], assessed the performance of a vegetable transplanter in both tilled and no-till soils. To allow the machine work properly in no-tilled soils, the authors modified a commercial manually fed vegetable transplanter [55]. To cut the cover crop residues, a $30 \mathrm{~cm}$ smooth coulter (manufactured by OFAS S.p.a., Mussolente, Vicenza, Italy) was installed directly under the frame. Furthermore, two types of shank opener (ripper shank opener and chisel shank opener) with two different points (nose point and winged point) were tested in order to evaluate the best combination of tools. In this way, the machine allows a wide furrow to be opened to facilitate the seedlings establishment. The combination of ripper shank openers and straight nose points provides the low power requirement for the machine, making this combination of tools the most suitable for no-till soils (Figure 2).

Also Kornecki and Price [56] used a similar solution outside of the Mediterrean Basin, modifying a single row No-Till plug transplanter (RJ Equipment ${ }^{\circledR}$, Blenheim, ON, Canada NOP 1A0) to assess the feasibility of more sustainable vegetable production practices. This trial was able to directly transplant cash crop seedlings in different high cover crop residues. The vegetable transplanter was equipped with a custom designed subsoiling shank in order to mitigate soil compaction and with row cleaners (Yetter ${ }^{\mathrm{TM}}$, PO BOX 358109 S. McDonough, Colchester, IL 62,326 USA) to manage cover crop residues and facilitate transplanting. Despite volumetric soil moisture content being higher where cover crops were used, yields of cash crops were consistently higher for the CT system compared with NT system. However, intermediate forms of non-ploughing or non-inversion tillage, such as MT, have been adopted more readily than NT and are sometimes suggested as a preliminary practice before starting NT [38]. 


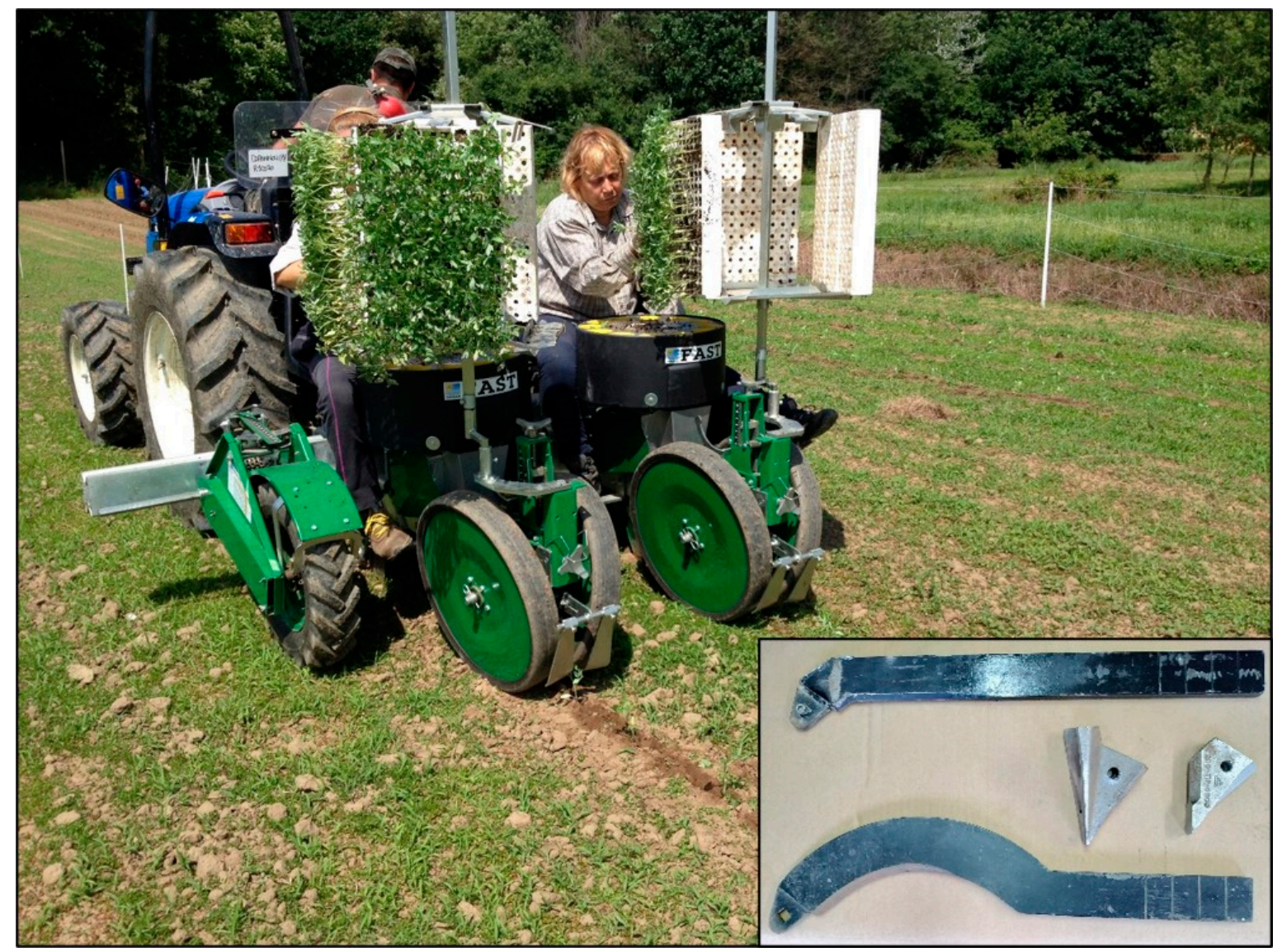

Figure 2. Two-row no-till transplanter realized at the University of Pisa and details of the two shanks opener and points used.

Minimum tillage (MT) represents those practices carried out at $10 \mathrm{~cm}$ maximum, able to obtain a good seedbed and maintain crop residues for about $30 \%$ of total surface. Often, under this definition are also included those practices carried out at higher depths and with more invasive machines. In this sense, it seems more appropriate to define reduced tillage practices (or even limited tillage or surface tillage or non-inversive tillage), meaning all those techniques that provide for a reduction in the number and intensity of soil tillage compared to the traditional seed-bed preparation. The traditional techniques include deep ploughing (conducted at a soil depth ranging from $25-30 \mathrm{~cm}$ and more than $50 \mathrm{~cm}$ ) and numerous other tillage interventions (conducted with rigid or elastic tine or disc harrows, rotating harrows and/or rotating hoe, etc.) for refining clods (i.e., conventional tillage) [15] As an alternative to the MT practices, RT provides to a primary tillage and sowing confined to the formation of raised ridges or beds in rows often on a contour. It is mainly used for maize and soybean cultivation and is currently interesting for its Precision Agriculture applications. RT is a specific soil management practice that requires wide row crops and also the use of specific machinery. For this reason, RT is confined to small areas of the Mediterranean Basin where wide row crops are grown. Conversely, in the US and in Australia, RT is a more widespread technique. Other types of conservation tillage concern zone tillage (or even strip tillage (ST)) and mulch tillage. The first consists in a primary partial-width tillage (i.e., full-width tillage, tillage conducted over the entire soil surface; partial-width tillage, tillage conducted over a proportion of the soil surface) for row crops confined to bands of $15 \mathrm{~cm}$ width and 5-8 $\mathrm{cm}$ depth, separated by bands of undisturbed soil, to form a seedbed for each row (Figures 3 and 4 ). This practice also refers to the general tilling of much wider strips of land (100 or more meters wide) on the contour, separated by wide fallowed strips, as an erosion control measure based on tillage [15]. Mulch tillage (or even stubble mulching, trash farming, sod farming, live mulch system) represents a form of full-width shallow primary tillage used prior to crop planting and provides a 
high percentage of crop residues retained at the soil surface [37]. A study carried out in Turkey [57] compared five different tillage and sowing methods for maize: (i) MT including tillage with a rotary tiller at a depth of $15 \mathrm{~cm}$ and final preparation with a scraper in twice; (ii) band tillage including band tillage with a crop rotary tiller at a depth of $15 \mathrm{~cm}$ and final preparation with the float in twice; (iii) RT including tillage with a disc harrow at a depth of $18 \mathrm{~cm}$ creating ridges with a lister and final preparation with the ridge float in once; (iv) NT including direct sowing in the previous crop residue by using a no-tillage planter; and (v) conventional tillage without stubble, including stubble burning, tillage with a disc harrow at a depth of $18 \mathrm{~cm}$ in twice and final preparation with the float in twice. Results showed that MT represents the best practice also compared with Band Tillage and RT, according to the significant environmental benefits that can be obtained with the adoption of a reduced tillage system; while the lowest work time and fuel consumption were observed in the NT practice. Moreover, the findings of this study stated that the highest productivity was in MT, followed by NT, CT, RT and BT. Most of the literature on strip tillage concerning field trials was carried out in Northern USA and Canada and then has been validated for soils and climates different from the Mediterranean area. Few studies have been carried out for Southern Europe environments. Gemtos et al. [58] used a strip tiller with a rotary tool to prepare a seedbed for cotton. Stathakos et al. [59] used a heavy cultivator-ridger at $0.27 \mathrm{~m}$ depth for primary tillage, a ground driven rotary cultivator-ridger at $0.09 \mathrm{~m}$ depth and a roller packer-ridger for seedbed preparation with a working width of $1.92 \mathrm{~m}$. The results of these two research projects showed that RT could offer some advantages like reduced energy requirements, reduced costs and higher yields than CT. However, cotton is not a widespread crop in Mediterranean areas. In the same period, six tillage methods for sunflower crop were tested and compared in South-eastern Turkey to investigate the effects of CT, RT and NT practices on sunflower yield and fuel consumption. In particular, RT was carried out by different machines: (i) disc harrow + float + direct seeding machine; (ii) rotary strip tiller + float + direct seeding machine; (iii) cultivator + float + ridge tillage + direct seeding machine; and (iv) cultivator + float + direct seeding machine. The fuel consumption was higher and the field efficiency lowest in CT practices as compared to the other tillage managements. In particular, the lowest consumption was recorded with strip tillage practices $\left(11.6 \mathrm{~L} \mathrm{ha}^{-1}\right)$ and NT $\left(6.6 \mathrm{~L} \mathrm{ha}^{-1}\right)$ [60]. Some years later, a row crop rotary hoe with C-type blades was used to obtain different strip widths, during a two-year field experiment in Turkey by Altikat [61]. The aim was to assess the effects of strip width and tractor forward speed on sowing uniformity of maize and sunflower. The findings revealed strip width was not affected by sowing uniformity while the most acceptable tractor speed was $0.5 \mathrm{~m} \mathrm{~s}^{-1}\left(1.8 \mathrm{~km} \mathrm{~h}^{-1}\right)$ for both crops. A study by Trevini et al. [62] was carried out to evaluate strip tillage compared to other soil tillage techniques, MT and NT aimed at maize seedbed preparation in the Po valley (Italy) as a representative crop and environment for Italian and Southern Europe intensive agriculture. The test was carried out by an original passive-tool implement for strip tillage, MT at a working depth of $25 \mathrm{~cm}$ and $35 \mathrm{~cm}$, and NT. Concerning the strip tillage machine, each working unit consisted of a sequence of row cleaner (to clean the seeding line from clods and residues), adjustable rubber wheel (to detect soil surface and keep a constant working depth) and cutting disc, shank with tine plus a couple of side closing discs (to contain the clods within the strip) and a final roll (to break clods and firm the seedbed). The results showed that strip tillage allowed a seedbed preparation not different from MT but moved less soil volumes, left higher ground residue cover, produced similar total biomass and grain yields. All these differences imply well-known economic and environmental benefits. At the same time, the authors proved that maize growth and yield were also quite high for NT, and this raises questions about the actual convenience of soil tilling instead of drilling directly on undisturbed soil. Benincasa et al. [63] compared three tillage-sowing treatments in order to develop hybrid machines to strip till and sow: (i) strip tillage plus volumetric band ( $0.1 \mathrm{~m}$ wide) seeding carried out by a Claydon Hybrid $6 \mathrm{M}$ at inter axle spacing of $0.6 \mathrm{~m}$ and with $35 \mathrm{~kg} \mathrm{ha}^{-1}$ of seeds; (ii) NT plus precision line planting carried out by a sod 
planter Kinze 3100 at row distance of $0.71 \mathrm{~m}$; (iii) strip tillage plus precision line planting carried out by a strip tiller Khun Striger at inter axle spacing of $0.71 \mathrm{~m}$ plus the Kinze 3100 and precision sod planter Kinze 3100. The research starts from the observation that a solution for developing a hybrid machine to strip-till and sow all crops, without affect crop performances, could be realised by regulating row spacing together with moving from line to banded seed placement. The results showed that a silage maize crop can achieve good crop performances when cultivated by strip tillage practices associated with volumetric band seeding. Moreover, the authors stated that similar results could be provided for highdensity crops like winter cereals by realizing environmental and economic benefits due to a reduction of the machinery pool and an optimization of operational crop management [57].

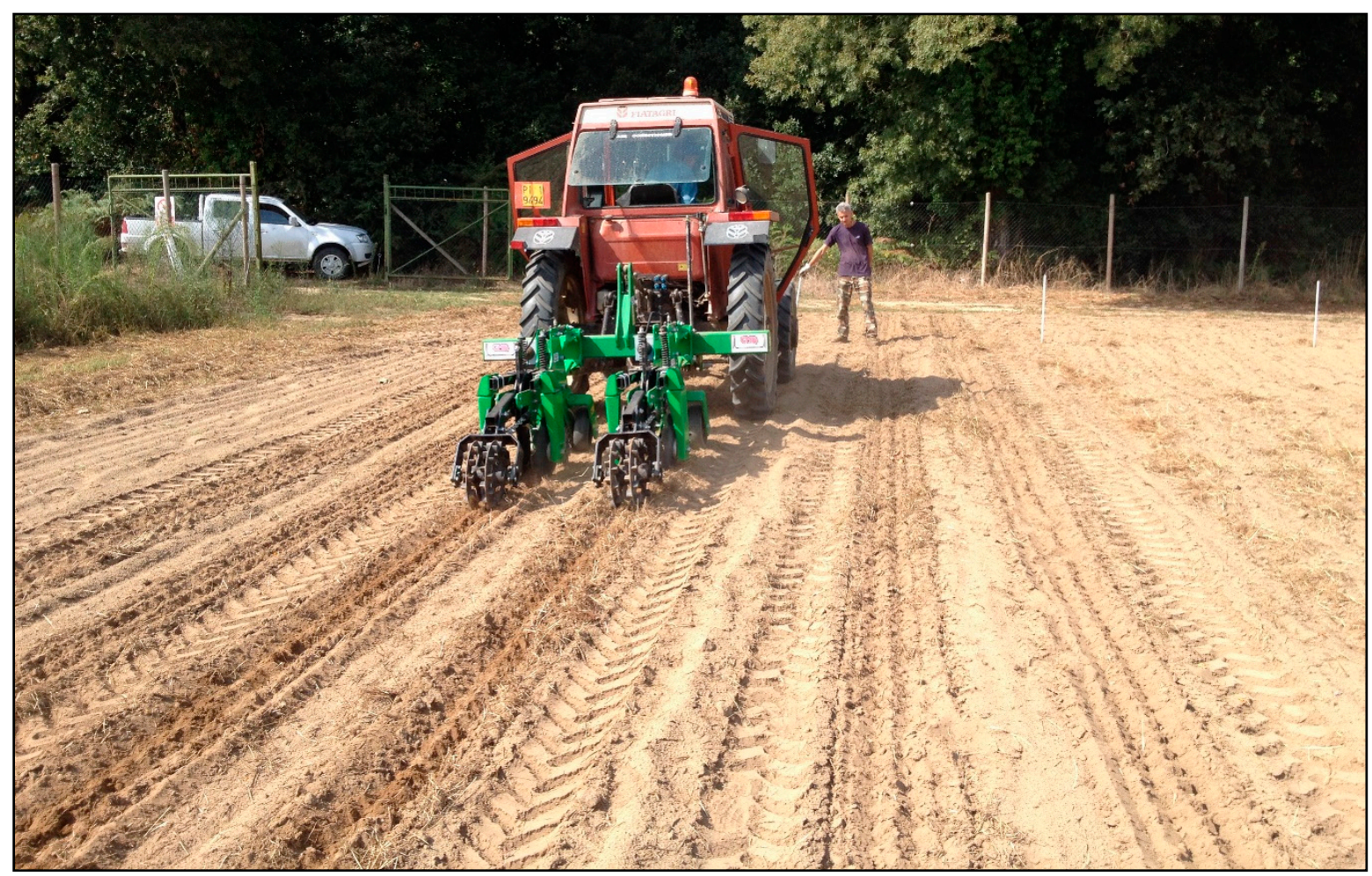

Figure 3. Prototype of a strip tiller realized by CMA Machine Agricole srl tested at the University of Pisa.

The agricultural machines industry is also producing new implements used to generate basins and reservoirs that apparently have some advantages over those used in CA practices, especially under sprinkler irrigation systems in the Mediterranean countries [64]. In order to prevent surface runoff and soil erosion, combined implements were developed in the last few years. These machines can control weeds mechanically, apply fertilizers and perform a furrow diking operation in a single passage. Although it is possible to find in the market different types of these machines, there are no published studies about their real field performance [64]. Regarding the management of horticultural crops under MT and particularly strip tillage, Brainard and Noyes [65] compared the effects of CT and ST on carrot yields and quality. ST produced equivalent or even greater carrot yields and equivalent or lower summer annual weed densities compared to CT, demonstrating that ST can be a valid tool for improving carrot production. Haramoto et al. [66] tested CT and ST in combination with an oat cover crop to evaluate the differences of cabbage yields. At the end of both years of the trial, no differences were observed in cabbage yields, proving that ST production systems associated with cover crops may be used without compromising crop yields. An important study regarding the use of strip tillage was conducted out of the Mediterrean Basin by Licht and Kaisi [67] at Iowa State University to assess strip tillage effects on seedbed soil temperatures and soil properties. For their study, Licht and Kasi 
used a four-row rotor tiller with blades $13 \mathrm{~cm}$ long and curved $5 \mathrm{~cm}$ at the end, with a soil disturbance of $20 \mathrm{~cm}$ in width and $10-15 \mathrm{~cm}$ in depth. Soil temperature was slightly higher with ST compared to NT $\left(1.2-1.4^{\circ} \mathrm{C}\right)$ and contributed to improve plant emergence. Soil moisture was also slightly higher with ST. Overstreet and Hoyt [68] used a Bush Hog RoTill (Bush Hog, Selma, AL, United States of America-USA) to strip-till their plots in order to assess biological and physical soil properties in the region from row to interrow. The Bush Hog RoTill strip-tiller had a subsoil shank adjusted to a depth of 20 to $23 \mathrm{~cm}$ to remove compaction in the root zone just under the row, creating strips 20 to $30 \mathrm{~cm}$ wide at the surface. The results suggest that there is no gradient effect for biological activity in ST systems from row to interrow for organically managed systems. Another study carried out in the United States [69] compared two muskmelon (Cucumis melo) production systems: ST on a rolled cover crop of cereal rye (Secale cereale) and CT with plastic mulch. Soils managed with ST were cooler and had more moisture. However, marketable yields were reduced slightly with ST. Jokela [70], tested organic NT and ST, compared with CT for the production of organic bell pepper and broccoli using a Hiniker 6000 strip tiller (Hiniker Co., Mankato, MN, USA). Jokela [70] also used a cover crop mixture of cereal rye (Secale cereale L.) and hairy vetch (Vicia villosa Roth) seeded on all plots and tilled in CT or rolled with a roller-crimper in NT and ST before planting in spring. The effects of NT and ST on crop yields varied during the two years of the trial. ST and NT reduced broccoli yield during the first year, but during the second year there was no difference with CT. Pepper yields behaved inversely, with no differences during the first year and a reduced production for ST and NT during the second year of the trial.

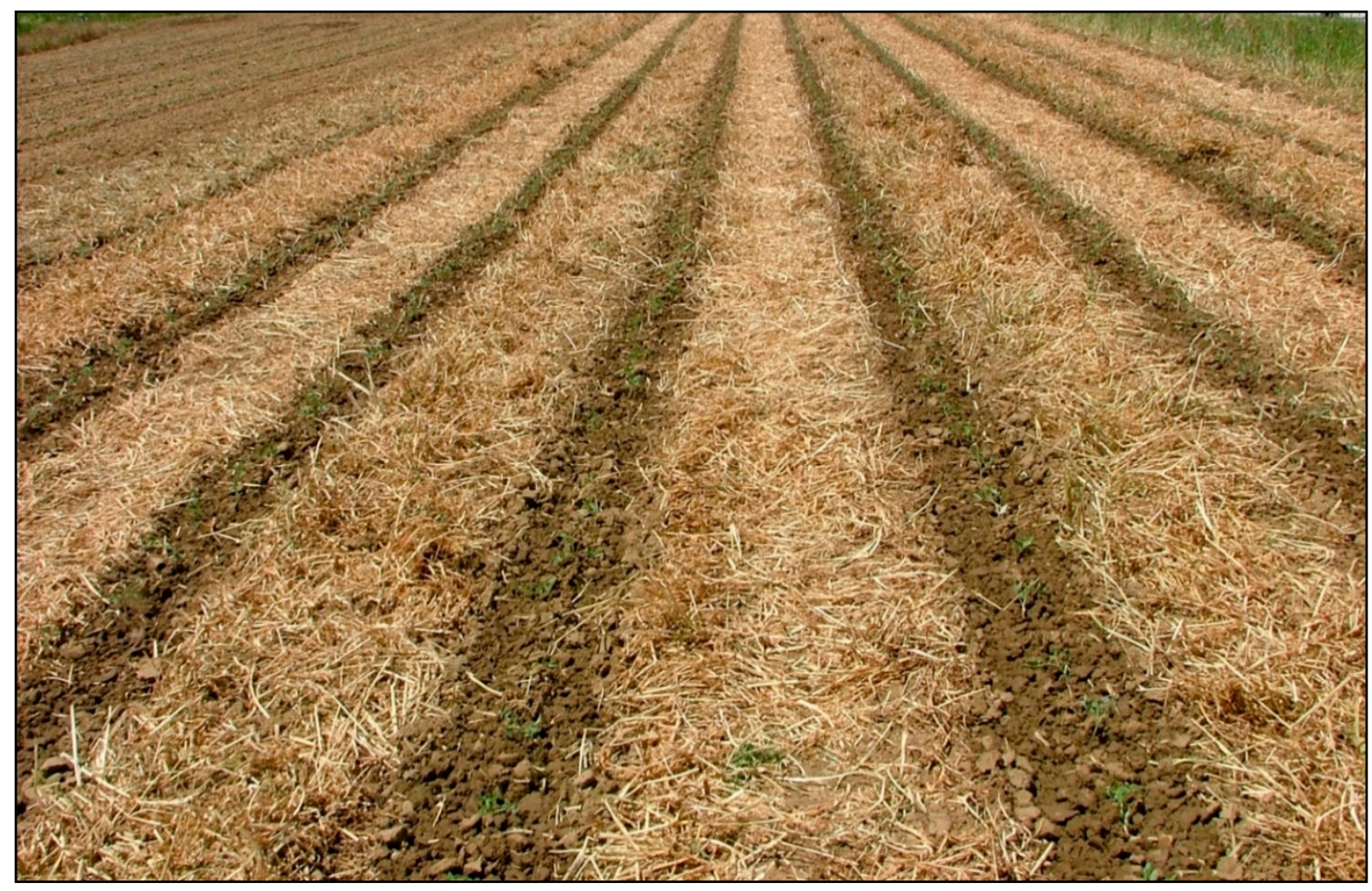

Figure 4. Effect of strip tillage on soil covered by dead mulch and tomato seedlings direct transplanted.

\subsection{Weed Control}

Reduced or no-tillage practices may increase weed spreading due to the lower soil disturbance compared to CT practices [71]. Despite adopting crop rotations that significantly reduce weeds pressure and avoid replacement flora selection, weed control issues are exacerbated by MT practices due to seeds accumulation in superficial soil layers. Weed flora 
in arable fields is strongly affected by agronomic practices such as tillage and fertilization management and some weed species are promoted by NT or RT. A seven-year study carried out in South Italy on a long-term durum wheat-faba bean rotation showed clear evidences that the effect of tillage on the overall weed community was more evident than that of nitrogen supply [71]. Combining NT techniques and cover crops either as living or dead mulch, Antichi et al. [72] tested the performance of an innovative organic and conservation vegetable system. The trial consisted of a three-year field experiment on savoy cabbage (Brassica oleracea var. sabauda L. cv. Famosa F1, Bejo), spring lettuce (Lactuca sativa L. cv. Justine, Clause), fennel (Foeniculum vulgare Mill. Cv. Montebianco F1, Olter), and summer lettuce (L. sativa L. cv. Ballerina RZ, Rijk Zwaan) crop rotation. The termination of cover crops (CC) as well as the management of crop residues and living mulch was implemented by rolling with a roller crimper alternated with flaming (Figure 5) [73].

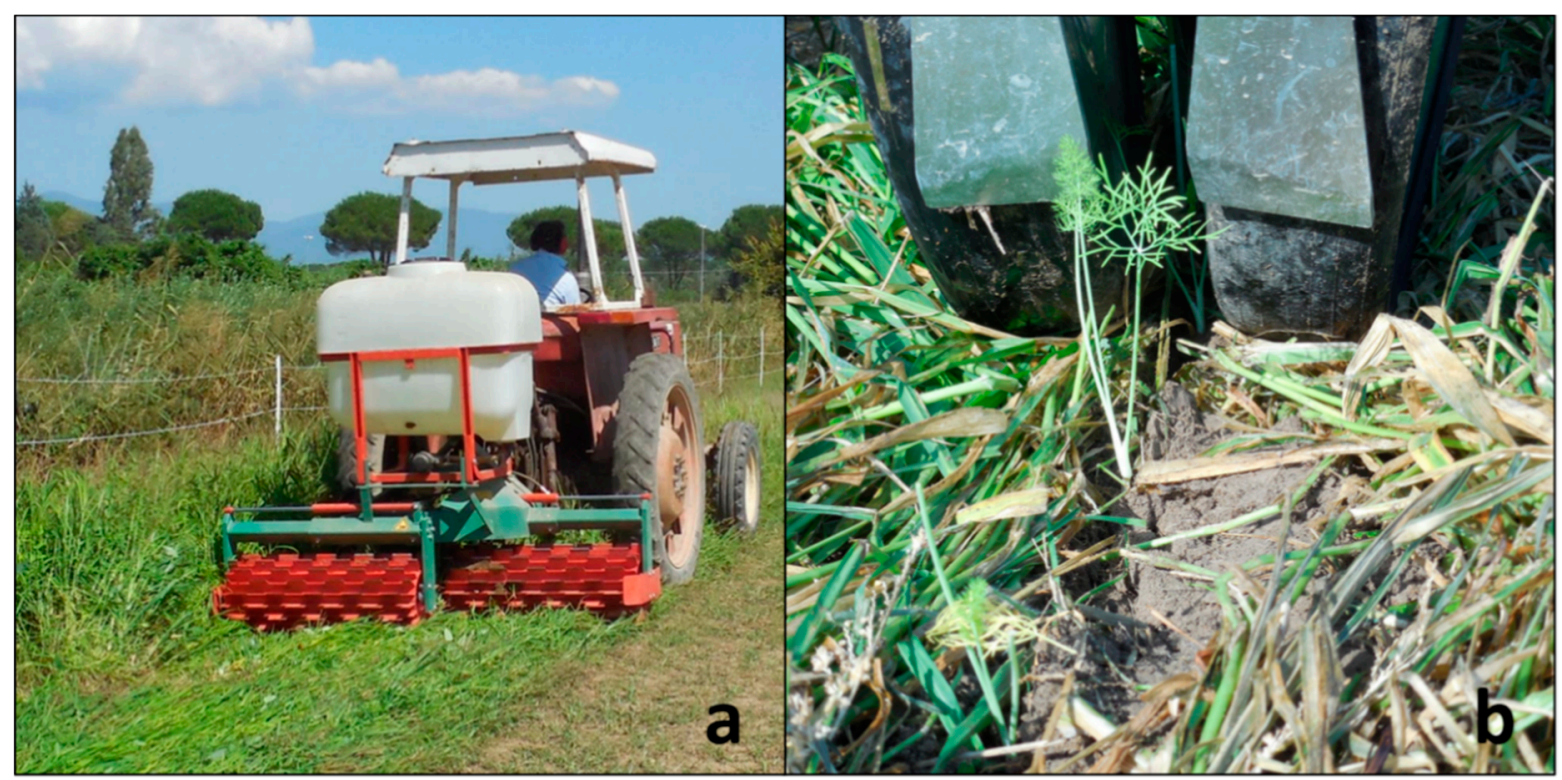

Figure 5. Clemens ballasted crimper roll (Clemens technologies, Wittlich, Germany) used to terminate a cover constituted by a mixture of rye and vetch at Pisa University at work (a) and detail of a well transplanted plant of fennel on the rolled cover with the transplanter developed at the University of Pisa (b).

The results confirmed that cover crops could be valuable tools in conservative lowinput systems, however crop yields and $\mathrm{N}$ uptake were significantly affected. These findings confirm that while some weed species could be inhibited in conservation tillage systems, more often weed infestation is a severe issue under conservation tillage, affecting crop yield. Furthermore, the effects of tillage systems on weeds happened to be site-specific and can get some advantages and disadvantages [74]. In this regard, weed management is a key issue hindering strip tillage adoption. A reason can be found in the high weed survival and reproduction in the untilled portion. However, annual, biennial, and perennial weeds have a different behaviour under strip tillage. The development of strategies involving high temperatures of about $55^{\circ} \mathrm{C}$, used to kill the weeds by destroying the cell wall structures, is prevalent in European countries. Flaming offers the best control for broad-leaved weeds, whereas grasses are less susceptible; it has shown good results after weed emergence prior to crop emergence in potato, sugar beet, carrot, and cayenne pepper crops. In other studies, corn and sorghum were tolerant to flaming, whereas soybean and sunflower were susceptible. Steam and hot water are considered safer than flaming and without side effects, so their use is considered in precision weed management strategies and sustainable methods in European countries. Conversely, low-tech devices and flaming are effective for controlling weeds and are cheap, thus easily accessible also for farmers managing small/medium farms. Since the choice of the machines depends on crops, weeds and 
soil, and since yield losses should be avoided, a low-tech and low-cost device such as an intra-row cultivator equipped with a manual guidance system could be successfully used on herbaceous crops. Moreover, flaming in the intra-row could also be a valid alternative to mechanical tools working in the rows and could be integrated with inter-row cultivators for weed management in heat-tolerant crops. Weed harrowing can be used in narrow-row herbaceous crops. Intelligent camera-based systems capable of guiding mechanical and/or thermal weeding devices are effective but still too expensive to be transferred to small farms that prefer to adopt low-tech and low-cost solutions [74]. While herbicide-based weed control may be both biologically efficient and economically effective, this occurs not without environmental and labour costs. For these reasons new technologies and strategies for controlling crop weeds using automated robotic control could be applied also in CA. The findings of Blasco et al. [75] relating to a non-chemical weed controller for vegetable crops were derived from a cooperative French-Spanish project. This is made up of a robotic end-effector that killed weeds by producing an electrical discharge of $15 \mathrm{kV}$. Two machine vision systems were used. The first machine vision system was a colour camera to detect weeds in real time and discriminate between soil and plant pixels using a simple algorithm. The second machine vision system was a monochromatic camera connected to a specific processing unit to provide trajectory information for the end-effector when positioning the electrical probe to kill weeds. In a field test, the machine vision system was able to correctly detect $84 \%$ of the weeds by their size and $99 \%$ of the lettuce plants. The positioning errors were lower than expected, which could be explained by the low speed of the machine and the smoothness of the ground. The authors concluded that a considerable amount of research was conducted on various machine vision techniques for weed detection and identification with a species classification accuracy in the range of $65-95 \%$. However, the most common source of error was due to occlusion between crop and weed and leaf appearance was sometimes distorted by environmental conditions (wind, insect or weather damage, water or nutrient stress, shadows). An integrated weed management based on advanced non-conventional strategies could be a pragmatic option in smart and modern agriculture.

\subsection{Cover Cropping}

Sustainable weed management involves numerous practices, such as crop rotation, cover crops, cultivations, weeding, flaming, biocontrol, weed seed predation, smoother crops, competition, mulching, natural herbicides and allelopathy [76-78]. In particular, CC provide advantages such as protection from soil erosion, enrichment of soils nutrient, contrast to compaction, control of soil moisture and organic matter increase, which are included within CA principles. The use of CC positively influences aggregation of soil particles and bio-geo-chemical cycles of carbon and nitrogen, determining an indirect effect on crop productivity. Moreover, the use of different plant species as cover crops, which alternate in time on the same plot, allows a different root depth (and therefore a distribution of new humus), with important effects on physical and chemical fertility [79]. CC practices also improve the $\mathrm{N}$ recycling at the agroecosystem level [80]. CC also prevent soil temperatures reaching high values, especially in hot and dry environments, and protect the soil from erosion [81], leaching, compaction and surface crusting phenomena, favouring water retention and infiltration and stability of aggregates [82]. Also, Perego et al. [83], in a 3-year test on 20 farms in the Po Valley found an improvement of soil characteristics with conservative practices compared to conventional ones. Massaccesi et al. [84], found a higher total organic $\mathrm{C}$ and higher concentration of microbial communities in the soil after three years of mulch-based cropping system. However, the adoption of cover crops involves management and economic issues that should provide for a perfect integration between main and catch crops. Also, CC management costs should be minimized, in order to optimise the agronomic and environmental outcome also in terms of biodiversity [85]. The NT practices can help to reduce costs and may give the possibility to seed the CC together with the harvesting of the previous crop. This is accomplished by means of 
combined harvesters equipped for a spread distribution of the seed immediately after the cutting bar and, therefore, before the straw falls on the ground. This practice, however, must forecast a certain soil moisture but also the possibility of chopping the straw to ensure crop germination and growth. In an integrated management approach, combining flaming and roller crimpers could be a viable solution to avoid using herbicides for cover crop termination [73]. Going into detail, CC termination and transformation in dead mulch can be successfully carried out by performing open flaming after rolling with a crimper roll. Moreover, flaming can be used to perform weed control in the inter-row space of the crops. For this purpose, a Clemens crimper roll and a MAITO (Maito srl, Arezzo, Italy) flamer equipped with four $0.5 \mathrm{~m}$ wide open burners can be used [73]. Another strategy to minimize CC management costs could be to use small autonomous machines such as autonomous mowers. Small autonomous machines in agriculture provide several advantages as a consequence of their low energy consumption, reduced ground pressure, low functioning overlap, and cost [86]. Sportelli et al. [87] found that autonomous mowers moving with random trajectories can efficiently work in narrow spaces such as horticultural fields (Figure 6). Furthermore, the high mowing frequency allowed control of weeds requiring a significant lower amount of primary energy and lower $\mathrm{CO}_{2}$ emissions compared with conventional management systems [88].

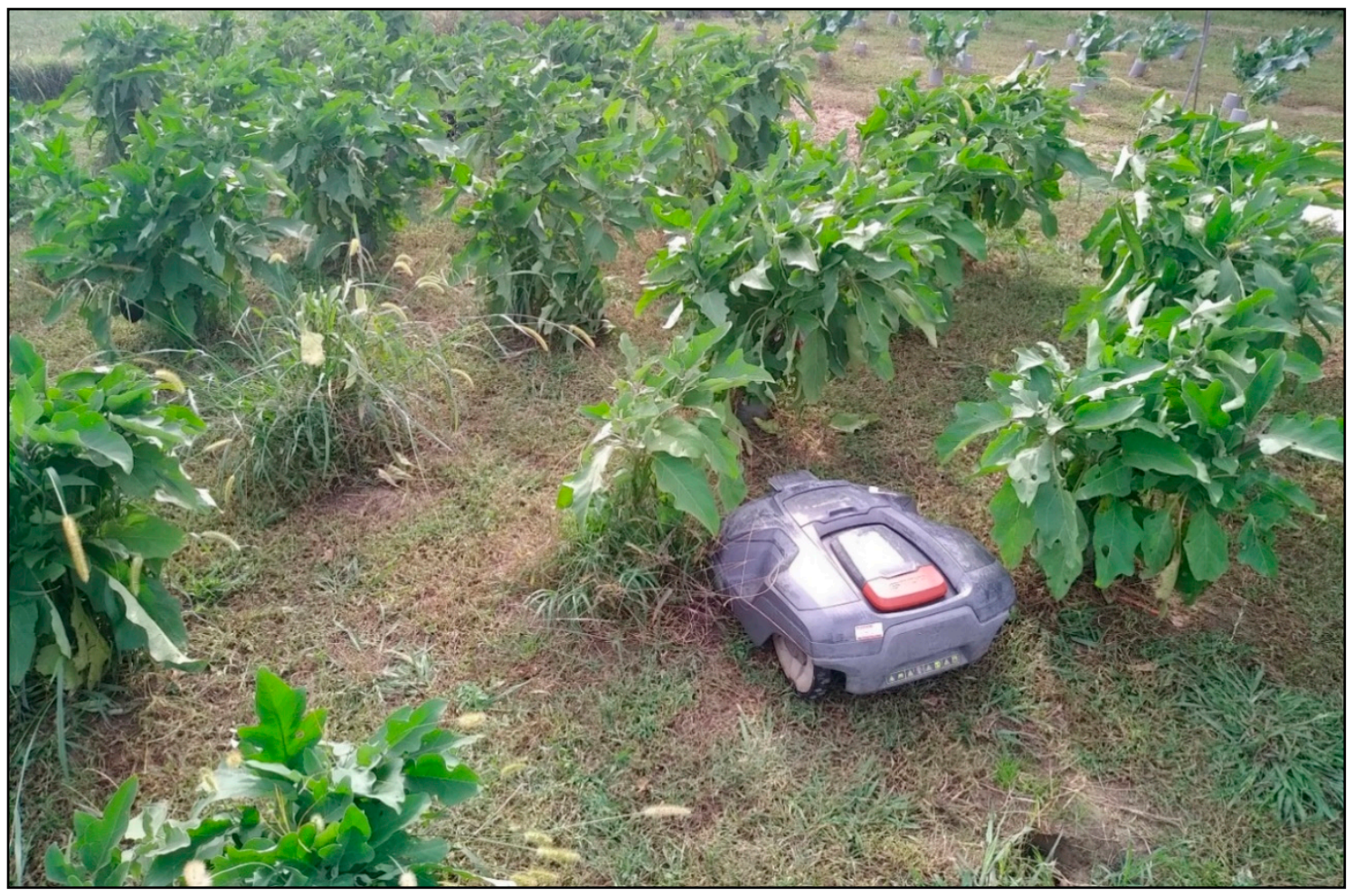

Figure 6. Autonomous mower managing living mulch in aubergine test field at the University of Pisa.

3. Evaluation of the Agronomic Performance of the Application of the Smart Strategies and Innovative Agricultural Machinery Used for Conservation Agriculture (CA)

\subsection{Crop Yield}

Many studies have been carried out in Mediterranean areas to compare the effects of several conservation tillage practices with those of conventional ones on yields of cereals, legumes, etc. These studies showed inconsistent yield results, as well as significant differences from one year to the other and from one site to the other, showing that crop response to specific practices could differ as a function of soil type and other associated management practices [89-95]. Moreover, the findings of these studies suggest that the 
adoption of soil conservation tillage is practicable for different cropping systems that reach equivalent or better performances than $\mathrm{CT}$.

By referring to the period examined (2000-2019), one of the oldest studies in these concerns has shown that MT with a rototiller was the most sustainable practice because of the increase of wheat grain yield (Triticum aestivum L.) and the improvement of soil physical properties over the long term compared with CT and MT with disc in Turkey [96]. In Central Italy, an experiment carried out on maize and soybean compared conventional mouldboard ploughing (CT), MT (by using two orthogonal rotary harrow passes for every year), RT (ridging with a $0.7 \mathrm{~m}$ spacing using a furrow opener and annually restored by means of a light ridging pass on the following years) and NT. This experiment showed that no significant differences due to soil tillage were found for grain yield and irrigation water use efficiency, except for soybean in only one year, in which yields and irrigation water use efficiency were $59 \%$ higher on conservation tillage treatments compared with CT [89]. Ruisi et al. [94] carried out a set of experiments in the South of Italy (Sicily Region) during 20 years in order to compare the effects of NT practices and CT on the productivity and quality of durum wheat. They showed that, in the semiarid Mediterranean environments, the factor that most affects wheat productivity is soil water availability, which is greater for the crop in NT than in CT. For these reasons, the yield differences between NT and CT noted during the trial were related to the water stress level suffered by wheat during its growing period. In particular, the regression analysis revealed the superiority of the NT approach over the CT technique with respect to the tillage practices when grain yields were low and, conversely, an advantage of CT in the opposite case. On average, no differences in yield were observed between the two tillage techniques as reported in other studies carried out in similar environmental conditions [90,91,93]. Moreover, in order to emphasise the potential of the NT technique, the authors suggest that the farmer needs to: (i) adopt a rational crop sequence, because a cumulative detrimental effect of NT with time was found for continuous wheat cultivation, probably as a consequence of the progressive increase in the incidence of certain residue-born pathogens of wheat; and (ii) with respect to the system managed with $\mathrm{CT}$, increase the rate of $\mathrm{N}$ fertiliser to compensate for the lower $\mathrm{N}$ availability in the soil that occurs in NT versus CT (as a consequence of both the reduction of the rate of mineralisation of the organic matter and the increase in $\mathrm{N}$ losses) [94]. A similar study carried out in Spain by Lampurlanés et al. [97] demonstrates that under semi-arid rain-fed conditions, soil water storage increases with the use of conservation tillage systems, being amplified with the degree of aridity of the site, leading to a greater crop yield. A study of Canakci et al. [44] was carried out in Turkey with the aim of assessing performances of a no-till seeder equipped with a double disc-type furrow opener, under dry and wet soil conditions using maize (Zea mays L.), cotton (Gossypium hirsutum L.), and soybean (Glycine max L.) seeds sown following wheat (Triticum aestivum). The results showed that the percentage of emergence of soybean plants in dry soil conditions was low while the percentage of emergence of maize and soybean in wet soil was higher. Also, sowing depth uniformity was better in wet soil than in dry soil. In general, there was acceptable data variability for sowing maize and cotton in dry and wet soils and for soybean into wet soil as concerns evaluated indices (mean emergence time, percentage of emergence, multiple index, miss index, quality of feed index, precision index of horizontal distribution pattern, and sowing depth uniformity). The study of Troccoli et al. [95] reports findings from national and international scientific literature and also some results of a long-term experimentation conducted in the South of Italy (Puglia Region). This study shows the effects of CA on crop yields show controversial results but, in general, yields are less than in CT with mouldboard ploughing. Sometimes NT can produce equivalent or greater yields than CT especially in dry climates [91,98-100]. This means that CA should not lead to yield penalties [16]. However, the different environmental conditions and the time of transition from conventional agriculture to the permanent state of CA strongly affect the grain yields. However, Ceccanti et al. [101] found a significantly higher level of bioactive compounds in leafy vegetables in a short-term experiment with a CA cropping 
system. These results greatly support CA practices despite yield losses. At the same time, soil properties could benefit from CA practices. Organic matter increases with CA and, consequently, increase underground water quality, reducing erosion processes and improving soil moisture retention. In this way also biodiversity is higher with NT than CT [95,102]. In France, Legrand et al. [102] highlighted the species richness and evenness significantly higher in fields under MT practices than in fields under CT, despite the fact that the core microbiota was similar between fields under these two practices. Other studies carried out in southern Italy [103] showed that no significant differences were revealed between the soil tillage treatments on Brassica carinata in terms of soil fertility comparing CT and MT. In particular, the CT practices included mouldboard ploughing $(40-45 \mathrm{~cm}$ deep) and both disk harrowing and vibrating tine cultivation; the MT practices involved two disk harrowing events with at least 7 days between them and just one instance of vibrating tine cultivation (10-15 cm deep). In the context of sustainable agriculture, the results of this study show that it is possible to sustain Brassica production and increase some nutrients in the soil with organic amendments (e.g., sewage sludge followed by the application of compost) and reduced tillage. Concerning bulk density, the findings are different. Some studies have reported a strong increase in bulk density with NT compared to mouldboard ploughing while others found similar bulk density values with CT and NT systems. Due to the rearrangement of soil sand particle aggregates by biological processes and by the action of coulters and shanks of no-till seeders and planters coulters, the layer from 0 to about $7 \mathrm{~cm}$ appears less compact than the underlying layers [95]. Moreover, other studies demonstrated that soil compaction values were frequently greater in NT systems than in CT, especially in the top layer. A field trial carried out in southern Italy, on a clay soil at the 10th year of NT, showed that usually NT had cone index values slightly higher than CT, excluding dry conditions and the thin soil layer $(0-0.15 \mathrm{~m})$ when NT soil looked to be less compact than CT [95]. The results of a study carried out in the North of Italy, alternating autumn and winter crops, provide insights on yields, $\mathrm{CO}_{2}$ emissions and SOC. In particular, SOC oxidation rates were overall lower under NT as well as the greatest reduction in $\mathrm{CO}_{2}$ emissions. These results underline the benefits of $\mathrm{NT}$ adoption in terms of soil fertility preservation and $\mathrm{CO}_{2}$ emissions mitigation also thanks to the lower number of passes required by NT practices and the higher working capacity of machinery used in NT. By contrast, NT practices achieved higher emissions from pesticides and sowing operations [41]. A study aimed at investigating the effects of CT, RT and NT practices on sunflower yields in South-eastern Turkey showed that sunflower yields and agronomic properties were significantly affected by tillage methods. In fact, the highest yields were found in CT methods and lowest yields were found in RT practices carried out by means of cultivator + float + direct seeding machine [60]. For the success of CA techniques and particularly of NT (transplanting on no tilled soil), in addition to a proper use of specific on purpose transplanter, there is a clear need to optimize the choice of the cover crops and to define and apply at best methods to terminate and transform them in dead mulch. These findings have been highlighted by the results obtained in horticultural crops by several authors in very recent field experiments on the use of a CA and organic agriculture management carried out in Italy (at the Universities of Pisa and Perugia). Moreover, there is also the need to set up strategies based upon the adoption of thermal and mechanical treatments able to guarantee good weed management after the transplanting [104].

\subsection{Economic Feasibility}

The estimation of production costs represents the most complex part of the economic evaluation given numerous variables to be considered. The technical analysis of production processes has shown that the main operation affected by changes in the transition from $\mathrm{CT}$ to $\mathrm{CA}$ is that concerning soil tillage. For this reason, the evaluation of the economic convenience between the two management systems should focus on this item. The first element of difference between CT and CA is represented by the reduction of interactions between operating machines and soil, limited to direct sowing in case of sod seeding. In 
terms of economical profitability, MT or NT may substantially reduce crop production costs, as mechanised tillage is a rather costly technique including fuel, labour and machinery costs. In the grain production systems, relative benefits of CA depend on the difference between the costs of soil tillage vs. the cost of chemical herbicides applied before sowing [95]. The reduced use of machines translates into savings due to the reduction of wear, fuel, lubricant and working time saving. In particular, experimental results confirm that, in general, the adoption of sowing on land allows significant savings to be attributed to lower (from $35 \%$ to $80 \%$ ) fuel consumption, a reduction (from $40 \%$ to $60 \%$ ) of time and labour costs (hours/machine and labour, spare parts and maintenance). Cost reduction is largely due to oil and energy saving [105]. Food and Agriculture Organization-FAO [8] reports economic benefits related also to labour savings and machinery depreciation, and some other authors report CA benefits on investments efficiency and productivity [106]. Labour requirements are generally reduced allowing farmers to save on time, fuel and machinery costs [16]. Apart from the agronomic and environmental benefits, this economic advantage proves to be a strategic element for the survival of many farms that face a globalized market with the prospect of a decrease in product prices and an uncertain international policy. In a recent study carried out in farms in central Italy that have long used cereal systems, it has been possible to verify that economic savings can be achieved by conservative agronomic practices compared to conventional ones, varying between 50 and 80 euros per ton of grain produced [107]. The economic convenience is strictly related to the machinery used. The technology currently available allows direct seeding to be carried out with specific seed drills that do not require any preparation of the seed bed. These machines are specifically designed to work on undisturbed soil in the presence of crop residues, equipped with appropriate devices for the prevention of seeding compacting and furrow closing, with recovering units and compressor parts, to guarantee regular plant emergence. According to Scopel et al. [108], for both resource use efficiency and socio-economic results, the situation becomes more favourable after some years of conservation agriculture application when systems stabilise. A comparative field experiment, based on direct measurements of data about machinery and production factors used, was carried out in the north of Italy, one of the main areas of rice production in Europe. The results showed that the adoption of conservative techniques led to significant savings on production costs, thanks to reduced work time ( $-47 \%$ for MT and $-61 \%$ for NT less) and to lower mechanisation costs $(-42 \%$ for MT and $-58 \%$ for NT) in comparison with CT practices. Moreover, the reduction in fuel consumption ( $-48 \%$ for MT and $-63 \%$ for NT) means reduction of emissions and environmental impacts [109].

\section{Conclusions}

The present review has led to the selection of several papers to highlight the importance of these issues in cropping systems, although more should be done in this research field. The studies taken into account in this paper were focused upon herbaceous and horticultural crops since they can be considered key food-products being highly representative of the Mediterranean agro-economy. Farmers play a crucial role in contributing to improving and increasing the sustainability and productivity of herbaceous and horticultural crops by means of the adoption of smart solutions for their conservative cultivation. However, farmers often find barriers such as inadequate policies, commodity based subsidies, direct farm payments, unavailability of appropriate machines (in many countries of the world) and suitable weed control practices to facilitate weed and vegetation management (especially for large scale farms in developing countries). Farmers are at the centre of any process of change that involves natural resources. For this reason they need to be encouraged and guided through appropriate incentives and governance practices to conserve natural ecosystems and their biodiversity, minimizing the negative impact that agriculture can have on the environment.

Future research activities are certainly needed to fully explore the potentialities of conservation and organic agriculture and precision farming, and to drive the transition 
process from conventional agriculture to an innovative management connected with the application of conservation, organic and precision farming techniques.

Author Contributions: Conceptualization, S.F., M.P., M.S., C.F. and A.P. methodology, S.F., M.P., M.S. and A.P.; validation, S.F., M.P., M.S. and A.P.; investigation, S.F., M.P., M.S. and A.P.; resources, A.P.; writing—original draft preparation, S.F., M.P. and M.S. writing—review and editing, S.F., M.P., M.S., A.P., C.F., M.F. and M.R.; project administration, A.P. and C.F.; funding acquisition, A.P. All authors have read and agreed to the published version of the manuscript.

Funding: This research paper was realized within the Project "Strategies and machines for a sustainable management of agricultural practices and not agricultural areas" funded by the University of Pisa. Scientific Responsible Andrea Peruzzi.

Institutional Review Board Statement: Not applicable.

Informed Consent Statement: Not applicable.

Data Availability Statement: No new data were created or analyzed in this study. Data sharing is not applicable to this article.

Conflicts of Interest: The authors declare no conflict of interest.

\section{References}

1. United Nations. Transforming our World. The 2030 Agenda for Sustainable Development, General Assembly. 21 October 2015. Available online: https:/ / sustainabledevelopment.un.org (accessed on 27 December 2020).

2. Govers, G.; Roel, M.; van Bas, W.; Van Kristof, O. Soil conservation in the 21st century: Why we need smart agricultural intensification. SOIL 2017, 3, 45-59. [CrossRef]

3. Joint Research Centre, European Commission. Soil Threats in Europe: Status, Methods, Drivers and Effects on Ecosystem Services. 2015. Available online: https:/ / ec.europa.eu/jrc (accessed on 27 December 2020).

4. European Environment Agency. State of the Environment Report; Copenhagen. 2010. Available online: www.eea.europa.eu (accessed on 27 December 2020).

5. European Commission. COM 571 fin, Roadmap to a Resource and Efficient Europe; Brussels, 20 September 2011. Available online: https: / / www.europarl.europa.eu/meetdocs/2009_2014/documents/com/com_com(2011)0571_/com_com(2011)057 1_en.pdf (accessed on 27 December 2020).

6. Knowler, D.; Bradshaw, B. Farmers' adoption of conservation agriculture: A review and synthesis of recent research. Food Policy 2007, 32, 25-48. [CrossRef]

7. Stach, A.; Podsiadłowski, S. Pulverizing and wind erosion as influenced by spatial variability of soils texture. Quaest. Geogr. 2002, 22, 67-78.

8. Food and Agriculture Organization (FAO). The Economics of Conservation Agriculture. Rome. 2001. Available online: http: //www.fao.org/3/y2781e/y2781e00.htm (accessed on 27 December 2020).

9. Food and Agriculture Organization (FAO). What is Conservation Agriculture? Rome. 2011. Available online: http://fao.org/ag/ ca/6c.html (accessed on 27 December 2020).

10. Civil Society Organizations (CSO) Panel. Land Rights for Sustainable Life on Land. UNCCD (United Nations Convention to Combat Desertification) Publications. 2017. Available online: https://www.unccd.int/sites/default/files/documents/2017-07/ CSO \%20Panel\%20-\%20Land\%20Rights.pdf (accessed on 27 December 2020).

11. Intergovernmental Panel on Climate Change (IPCC). Global Warming of $1,5{ }^{\circ}$ C., Special Report. 2018. Available online: https:/ / www.ipcc.ch/sr15/ (accessed on 27 December 2020).

12. United Nations Environment Programme (UNEP). Global Environment Outlook GEO4 Environment for Development. ISBN: 978-92-807-2836-1 (UNEP paperback) DEW/0962/NA. 2007. Available online: https://wedocs.unep.org (accessed on 27 December 2020).

13. Lal, R. Soil Carbon Sequestration Impacts on Global Climate Change and Food Security. Science 2004, 304, 1623-1627. [CrossRef]

14. Sims, B.; Corsi, S.; Gbehounou, G.; Kienzle, J.; Taguchi, M.; Friedrich, T. Sustainable Weed Management for Conservation Agriculture: Options for Smallholder Farmers. Agriculture 2018, 8, 118. [CrossRef]

15. Baker, C.J.; Saxton, K.E.; Ritchie, W.R.; Chamen, W.C.T.; Reicosky, D.C.; Ribeiro, M.F.S.; Justice, S.E.; Hobbs, P.R. No-Tillage Seeding in Conservation Agriculture, 2nd ed.; FAO and CAB International: Rome, Italy, 2007.

16. Marandola, D.; Belliggiano, A.; Romagnoli, L.; Ievoli, C. The spread of no-till in conservation agriculture systems in Italy: Indications for rural development policy-making. Agric. Food Econ. 2019, 7, 7. [CrossRef]

17. Hobbs, P.R. Conservation agriculture: What is it and why is it important for future sustainable food production. J. Agric. Sci. 2007, 145, 127-137. [CrossRef]

18. Olawuyi, S.O.; Mushunje, A. Social Capital and Adoption of Alternative Conservation Agricultural Practices in South-Western Nigeria. Sustainability 2019, 11, 716. [CrossRef] 
19. De Lucas, A.I.; Molari, G.; Seddaiu, G.; Toscano, A.; Bombino, G.; Ledda, L.; Milani, M.; Vittuari, M. Multidisciplinary and Innovative Methodologies for Sustainable Management in Agricultural Systems. Environ. Eng. Manag. J. 2015, 14, 1571-1581.

20. Deligios, P.A.; Chergia, P.A.; Sanna, G.; Solinas, S.; Todde, G.; Narvarte, L.; Ledda, L. Climate change adaptation and water saving by innovation irrigation management applied on open field globe artichoke. Sci. Total Environ. 2019, 649, 461-472. [CrossRef]

21. Lahmar, R. Adoption of conservation agriculture in Europe: Lessons of the KASSA project. Land Use Policy 2010, 27, 4-10. [CrossRef]

22. Acevedo, M.F. Interdisciplinary progress in food production, food security and environment research. Environ. Conserv. 2011, 38, 151-171. [CrossRef]

23. Nhamo, N.; Chikoye, D. Smart Technologies for Sustainable Smallholder Agriculture; Academic Press: Cambridge, MA, USA, 2017; pp. 1-20.

24. European Commission, COM 179 fin. Towards a Thematic Strategy for Soil Protection, Brussels, Belgium, 16 April 2002. Available online: https: / / eur-lex.europa.eu/LexUriServ /LexUriServ.do?uri=COM:2002:0179:FIN:EN:PDF (accessed on 27 December 2020).

25. Berge, H.F.M.; Schroder, J.J.; Olesen, J.E.; Giraldez Cervera, J.V. Research for AGRI Committee-Preserving Agricultural Soils in the EU, European Parliament, Policy Department for Structural and Cohesion Policies, Brussels 2017. Available online: http: / / www.europarl.europa.eu (accessed on 27 December 2020).

26. Frelih-Larsen, A.; Bowyer, C.; Albrecht, S.; Keenleyside, C.; Kemper, M.; Nanni, S.; Naumann, S.; Mottershead, D.; Landgrebe, R.; Andersen, E.; et al. Updated Inventory and Assessment of Soil Protection Policy Instruments in Eu Member States; Final Report to DG Environment; Ecologic Institute: Berlin, Germany, 2016.

27. European Parliament. Decision No 529/2013/Eu Of The European Parliament And Of The Council of 21 May 2013 on Accounting Rules on Greenhouse gas Emissions and Removals Resulting from Activities Relating to Land Use, Land-Use Change and Forestry and on Information Concerning Actions Relating to Those Activities. Available online: https:/ / eur-lex.europa.eu/legalcontent/EN/TXT/PDF/?uri=CELEX:32013D0529\&from=EN (accessed on 27 December 2020).

28. European Environment Agency. The Impact of EU Economic Sectors on land, Report n. 8. 2016. Available online: www.eea. europa.eu (accessed on 27 December 2020).

29. Lal, R. Managing world soils for food security and environmental quality. Adv. Agron. 2001, 74, 155-192.

30. Berry, J.K.; Delgado, J.A.; Khosla, R.; Pierce, F.J. Precision conservation for environmental sustainability. J. Soil Water Conserv. 2003, 58, 332-339.

31. Berry, J.K.; Delgado, J.A.; Pierce, F.J.; Khosla, R. Applying spatial analysis for precision conservation across the landscape. J. Soil Water Conserv. 2005, 60, 363-370.

32. Knight, B.I. Precision conservation. J. Soil Water Conserv. 2005, 60, 137A.

33. Kitchen, N.R.; Sudduth, K.A.; Myers, D.B.; Massey, R.E.; Sadler, E.J.; Lerch, R.N.; Hummel, J.W.; Palm, H.L. Development of a conservation-oriented precision agriculture system: Crop production assessment and plan implementation. J. Soil Water Conserv. 2005, 60, 421-430.

34. Basso, B.; Sartori, L.; Bertocco, M.; Cammarano, D.; Martin, E.C.; Grace, P.R. Economic and environmental evaluation of site-specific tillage in a maize crop in NE Italy. Eur. J. Agron. 2011, 35, 83-92. [CrossRef]

35. Kitchen, N.R. Emerging technologies for real-time and integrated agriculture decisions. Comput. Electron. Agric. 2008, 61, 1-3. [CrossRef]

36. Lovarelli, D.; Bacenetti, J. Seedbed preparation for arable crops: Environmental impact of alternative mechanical solutions. Soil Tillage Res. 2017, 174, 156-168. [CrossRef]

37. Carter, M.R. Conservation Tillage. Encycl. Soils Environ. 2005, 306-311. [CrossRef]

38. Soane, B.D.; Ball, B.C.; Arvidsson, J.; Basch, G.; Moreno, F.; Roger-Estrade, J. No-till in northern, western and south-western Europe: A review of problems and opportunities for crop production and the environment. Soil Tillage Res. 2012, 118, 66-87. [CrossRef]

39. Vincent-Caboud, L.; Peigné, J.; Casagrande, M.; Silva, E. Overview of organic cover crop-based no-tillage technique in Europe: Farmers' practices and research challenges. Agriculture 2017, 7, 42. [CrossRef]

40. Yezekyan, T.; Marinello, F.; Armentano, G.; Trestini, S.; Sartori, L. Definition of Reference Models for Power, Weight, Working Width, and Price for Seeding Machines. Agriculture 2018, 8, 186. [CrossRef]

41. Pezzuolo, A.; Dumont, B.; Sartori, L.; Marinello, F.; De Antoni Migliorati, M.; Basso, B. Evaluating the impact of soil conservation measures on soil organic carbon at the farm scale. Comput. Electron. Agric. 2017, 135, 175-182. [CrossRef]

42. Frasconi, C.; Martelloni, L.; Raffaelli, M.; Fontanelli, M.; Abou Chehade, L.; Peruzzi, A.; Antichi, D. A field vegetable transplanter for use in both tilled and no-till soils. Trans. Asabe 2019, 62, 593-602. [CrossRef]

43. Conceição, L.A.; Barreiro, P.; Dias, S.; Garrido, M.; Valero, C.; da Silva, J.R.M. A partial study of vertical distribution of conventional no-till seeders and spatial variability of seed depth placement of maize in the Alentejo region, Portugal. Precis. Agric. 2016, 17, 36-52. [CrossRef]

44. Canakci, M.; Karayel, D.; Topakci, M.; Koc, A. Performance of a no-till seeder under dry and wet soil conditions. Appl. Eng. Agric. 2009, 25, 459-465. [CrossRef]

45. Afify, M.T.; Kushwaha, R.L.; Gerein, M.A. Effect of combined disc angles on soil forces of coulter discs. In Proceedings of the ASAE Annual Meeting, Sacramento, CA, USA, 29 July-1 August 2001; pp. 1-14. 
46. Becker, F.; Voß, T.; Mohr, A.; Mehdorn, A.-S.; Schütte-Nütgen, K.; Reuter, S.; Kabar, I.; Bormann, E.; Vowinkel, T.; Palmes, D.; et al. Impact of nighttime procedures on outcomes after liver transplantation. PLoS ONE 2019, 14, e0220124. [CrossRef]

47. Karayel, D.; Šarauskis, E. Effect of down force on the performance of no-till disc furrow openers for clay-loam and loamy soils. Agric. Eng. 2011, 43, 16-24.

48. Malasli, M.Z.; Celik, A. Disc angle and tilt angle effects on forces acting on a single-disc type no-till seeder opener. Soil Tillage Res. 2019, 194, 104304. [CrossRef]

49. Altikat, S.; Celik, A.; Gozubuyuk, Z. Effects of various no-till seeders and stubble conditions on sowing performance and seed emergence of common vetch. Soil Tillage Res. 2013, 126, 72-77. [CrossRef]

50. Aikins, K.A.; Antille, D.L.; Jensen, T.A.; Blackwell, J. Performance comparison of residue management units of no-tillage sowing systems: A review. Eng. Agric. Environ. Food 2019, 12, 181-190. [CrossRef]

51. Morse, R. No-till vegetable production: Its time is now. HortTech 1999, 9, 373-379. [CrossRef]

52. Yoder, D.C.; Cope, T.L.; Wills, J.B.; Denton, H.P. No-till transplanting of vegetables and tobacco to reduce erosion and nutrient surface runoff. J. Soil Water Cons. 2005, 60, 68-72.

53. Mitchell, J.P.; Klonsky, K.M.; Miyao, E.M.; Aegerter, B.J.; Shrestha, A.; Munk, D.S.; Hembree, K.; Madden, N.M.; Turini, T.A. Evolution of conservation tillage systems for processing tomato in California's Central Valley. HortTech 2012, 22, 617-626. [CrossRef]

54. Morse, R.D.; Vaughan, D.H.; Belcher, L.W. Evaluation of conservation tillage systems for transplanting crops-Potential role of the subsurface tillage transplanter. The Evolution of Conservation Tillage Systems. In Proceedings of the Conservation Tillage Conference for Sustainable Agriculture, Monroe, LA, USA, 15-17 June 1993.

55. Fedele. "Fast" Transplanter. Lanciano, Italy: Fedele Costruzioni Meccaniche. 2017. Available online: http:/ / www.fedelemario. com/trapiantatrice\%20fast.html (accessed on 27 December 2020).

56. Kornecki, T.S.; Price, A.J. Management of High-Residue Cover Crops in a Conservation Tillage Organic Vegetable On-Farm Setting. Agronomy 2019, 9, 640. [CrossRef]

57. Barut, Z.B.; Ertekin, C.; Karaagac, H.A. Tillage effects on energy use for corn silage in Mediterranean Coastal of Turkey Zeliha. Energy 2011, 36, 5466-5475. [CrossRef]

58. Gemtos, T.A.; Cavalaris, C.C.; Karamoutis, C.; Fountas, S. Evaluation of strip tillage for cotton production in Greece. In Proceedings of the International Conference on Agricultural Engineering, Hersonissos, Crete, Greece, $23-25$ June 2008.

59. Stathakos, T.D.; Gemtos, T.A.; Tsatsarelis, C.A.; Galanopoulou, S. Evaluation of three cultivation practices for early cotton establishment and improving crop profitability. Soil Tillage Res. 2006, 87, 135-145. [CrossRef]

60. Sessiz, A.; Sogut, T.; Alp, A.; Esgici, R. Tillage effects on sunflower (Helianthus annuus) emergence, yield, quality and fuel consumption in double cropping system. J. Cent. Eur. Agric. 2008, 9, 697-710.

61. Altikat, S. Effects of strip width and tractor forward speed on sowing uniformity of maize and sunflower. Bulg. J. Agric. Sci. 2012, $18,375-382$.

62. Trevini, M.; Benincasa, P.; Guiducci, M. Strip tillage effect on seedbed tilth and maize production in Northern Italy as case-study for the Southern Europe environment. Eur. J. Agron. 2013, 48, 50-56. [CrossRef]

63. Benincasa, P.; Zorzi, A.; Panella, F.; Tosti, G.; Trevini, M. Strip tillage and sowing: Is precision planting indispensable in silage maize? Int. J. Plant Prod. 2017, 11, 1735-1804.

64. Silva, L.L. Are basin and reservoir tillage effective techniques to reduce runoff under sprinkler irrigation in Mediterranean conditions? Agric. Water Manag. 2017, 191, 50-56. [CrossRef]

65. Brainard, D.C.; Noyes, D.C. Strip tillage and compost influence carrot quality, yield, and net returns. Hortic. Sci. 2012, 47, 1073-1079. [CrossRef]

66. Haramoto, E.R.; Brainard, D.C. Strip tillage and oat cover crops increase soil moisture and influence $\mathrm{N}$ mineralization patterns in cabbage. Hortic. Sci. 2012, 47, 1596-1602. [CrossRef]

67. Licht, M.A.; Al-Kaisi, M. Strip-tillage effect on seedbed soil temperature and other soil physical properties. Soil Tillage Res. 2005, 80, 233-249. [CrossRef]

68. Overstreet, L.F.; Hoyt, G.D. Effects of strip tillage and production inputs on soil biology across a spatial gradient. Soil Sci. Soc. Am. J. 2008, 72, 1454-1463. [CrossRef]

69. Tillman, J.; Nair, A.; Gleason, M.; Batzer, J. Evaluating strip tillage and rowcover use in organic and conventional muskmelon production. Hortic. Technol. 2015, 25, 487-495. [CrossRef]

70. Jokela, D.L. Organic No-Till and Strip-Till Systems for Broccoli and Pepper Production. Master's Thesis, Iowa State University, Ames, Iowa, 2016.

71. Fracchiolla, M.; Stellacci, A.M.; Cazzato, E.; Tedone, L.; Alhajj Ali, S.; De Mastro, G. Effects of Conservative Tillage and Nitrogen Management on Weed Seed Bank after a Seven-Year Durum Wheat-Faba Bean Rotation. Plants 2018, 7, 82. [CrossRef]

72. Antichi, D.; Sbrana, M.; Martelloni, L.; Chehade, L.A.; Fontanelli, M.; Raffaelli, M.; Mazzoncini, M.; Peruzzi, A.; Frasconi, C. Agronomic performances of organic field vegetables managed with conservation agriculture techniques: A study from central Italy. Agronomy 2019, 9, 810. [CrossRef]

73. Frasconi, C.; Martelloni, L.; Antichi, D.; Raffaelli, M.; Fontanelli, M.; Peruzzi, A.; Benincasa, P.; Tosti, G. Combining roller crimpers and flaming for the termination of cover crops in herbicide-free no-till cropping systems. PLoS ONE 2019, 14, e0211573. [CrossRef] [PubMed] 
74. Peruzzi, A.; Martelloni, L.; Frasconi, C.; Fontanelli, M.; Pirchio, M.; Raffaelli, M. Machines for Non-Chemical Intra-Row Weed Control in Narrow and Wide-Row Crops: A Review. J. Agric. Eng. 2017. [CrossRef]

75. Blasco, J.; Aleixos, N.; Roger, J.M.; Rabatel, G.; Molto, E. Robotic Weed Control using Machine Vision. Biosyst. Eng. 2002, 83, 149-157. [CrossRef]

76. Barberi, P.; Mazzoncini, M. Changes in weed community composition as influenced by cover crop and management system in continuous corn. Weed Sci. 2001, 49, 491-499. [CrossRef]

77. Flamini, G. Natural herbicides as a safer and more environmentally friendly approach to weed control: A review of the literature since 2000. Stud. Nat. Prod. Chem. 2012, 38, 353-396.

78. Tabaglio, V.; Marocco, A.; Schulz, M. Allelopathic cover crop of rye for integrated weed control in sustainable agroecosystems. Ital. J. Agron. 2013, 8, 35-40. [CrossRef]

79. Gabriel, J.L.; Muñoz-Carpena, R.; Quemada, M. The role of cover crops in irrigated systems: Water balance, nitrate leaching and soil mineral nitrogen accumulation. Agric. Ecol. Environ. 2012, 155, 50-61. [CrossRef]

80. Tosti, G.; Benincasa, P.; Farneselli, M.; Guiducci, M.; Onofri, A.; Tei, F. Processing Tomato-Durum Wheat Rotation under Integrated, Organic and Mulch-Based No-Tillage Organic Systems: Yield, N Balance and N Loss. Agronomy 2019, 9, 718. [CrossRef]

81. Borrelli, P.; Panagos, P. An indicator to reflect the mitigating effect of Common Agricultural Policy on soil erosion. Land Use Policy 2020, 92, 104-467. [CrossRef]

82. Gabriel, J.L.; Quemada, M.; Martín-Lammerding, D.; Vanclooster, M. Assessing the cover crop effect on soil hydraulic properties by inverse modelling in a 10-year field trial. Agric. Water Manag. 2019, 222, 62-71. [CrossRef]

83. Perego, A.; Rocca, A.; Cattivelli, V.; Tabaglio, V.; Fiorini, A.; Barbieri, S.; Schillaci, C.; Chiodini, M.E.; Brenna, S.; Acutis, M. Agro-environmental aspects of conservation agriculture compared to conventional systems: A 3-year experience on 20 farms in the Po valley (Northern Italy). Agric. Syst. 2019, 168, 73-87. [CrossRef]

84. Massaccesi, L.; Rondoni, G.; Tosti, G.; Conti, E.; Guiducci, M.; Agnelli, A. Soil functions are affected by transition from conventional to organic mulch-based cropping system. Appl. Soil Ecol. 2020, 153, 103639. [CrossRef]

85. Diacono, M.; Ciaccia, C.; Canali, S.; Fiore, A.; Montemurro, F. Assessment of agro-ecological service crop managements combined with organic fertilisation strategies in organic melon crop. Ital. J. Agron. 2018, 13, 172-182. [CrossRef]

86. Bechar, A.; Vigneault, C. Agricultural robots for field operations. Part 2: Operations and systems. Biosyst. Eng. 2017, 153, 110-128. [CrossRef]

87. Sportelli, M.; Pirchio, M.; Fontanelli, M.; Volterrani, M.; Frasconi, C.; Martelloni, L.; Caturegli, L.; Gaetani, M.; Grossi, N.; Magni, M.; et al. Autonomous mowers working in narrow spaces: A possible future application in agriculture? Agronomy 2020, 10, 553. [CrossRef]

88. Magni, S.; Sportelli, M.; Grossi, N.; Volterrani, M.; Minelli, A.; Pirchio, M.; Fontanelli, M.; Frasconi, C.; Gaetani, M.; Martelloni, L.; et al. Autonomous Mowing and Turf-Type Bermudagrass as Innovations for An Environment-Friendly Floor Management of a Vineyard in Coastal Tuscany. Agriculture 2020, 10, 189. [CrossRef]

89. Casa, R.; Lo Cascio, B. Soil conservation tillage effects on yield and water use efficiency on irrigated crops in Central Italy. J. Agron. Crop Sci. 2008, 194, 310-319. [CrossRef]

90. Hernanz, J.L.; Lopez, R.; Navarrete, L.; Sanchez-Giron, V. Long-term effects of tillage systems and rotations on soil structural stability and organic carbon stratification in semiarid central Spain. Soil Tillage Res. 2002, 66, 129-141. [CrossRef]

91. De Vita, P.; Di Paolo, E.; Fecondo, G.; Di Fonzo, N.; Pisante, M. No tillage and conventional tillage effects on durum wheat yield, grain quality and soil moisture content in southern Italy. Soil Tillage Res. 2007, 92, 69-78. [CrossRef]

92. Mazzoncini, M.; Di Bene, C.; Coli, A.; Antichi, D.; Petri, M.; Bonari, E. Rainfed wheat and soybean productivity in a long-term tillage experiment in central Italy. Agron. J. 2008, 100, 1418-1429. [CrossRef]

93. Ruisi, P.; Giambalvo, D.; Di Miceli, G.; Frenda, A.S.; Saia, S.; Amato, G. Tillage effects on yield and nitrogen fixation of legumes in Mediterranean conditions. Agron. J. 2012, 104, 1459-1466. [CrossRef]

94. Ruisi, P.; Giambalvo, D.; Saia, S.; Di Miceli, G.; Frenda, A.S.; Plaia, A.; Amato, G. Conservation tillage in a semiarid Mediterranean environment: Results of 20 years of research. Ital. J. Agron. 2014, 9, 560. [CrossRef]

95. Troccoli, A.; Maddaluno, C.; Mucci, M.; Russo, M.; Rinaldi, M. Is it appropriate to support the farmers for adopting conservation agriculture? Economic and environmental impact assessment. Ital. J. Agron. 2015, 10, 661. [CrossRef]

96. Özpinar, S.; Çay, A. Effects of minimum and conventional tillage systems on soil properties and yield of winter wheat (Triticum aestivum L.) in clay-loam in the Çanakkale region. Turk. J. Agric. For. 2005, 29, 9-18.

97. Lampurlanés, J.; Plaza-Bonilla, D.; Álvaro-Fuentes, J.; Cantero-Martínez, C. Long-term analysis of soil water conservation and crop yield under different tillage systems in Mediterranean rainfed conditions. Field Crop Res. 2016, 189, 59-67. [CrossRef]

98. Colecchia, S.A.; Rinaldi, M.; De Vita, P. Effects of tillage systems in durum wheat under rainfed Mediterranean conditions. Cereal Res. Commun. 2015, 43, 4. [CrossRef]

99. Failla, S.; Ingrao, C.; Arcidiacono, C. Energy consumption of rainfed durum wheat cultivation in a Mediterranean area using three different soil management systems. Energy 2020, 195, 116960. [CrossRef]

100. Pisante, M.; Basso, F. Influence of tillage systems on yield and quality of durum wheat in Southern Italy. Ciheam Options Mediterr. 2000, 549-554. 
101. Ceccanti, C.; Landi, M.; Antichi, D.; Guidi, L.; Manfrini, L.; Monti, M.; Tosti, G.; Frasconi, C. Bioactive Properties of Fruits and Leafy Vegetables Managed with Integrated, Organic, and Organic No-Tillage Practices in the Mediterranean Area: A Two-Year Rotation Experiment. Agronomy 2020, 10, 841. [CrossRef]

102. Legrand, F.; Picot, A.; Cobo-Díaz, J.F.; Carof, M.; Chen, W.; Le Floch, G. Effect of tillage and static abiotic soil properties on microbial diversity. Appl. Soil Ecol. 2018, 132, 135-145. [CrossRef]

103. Debiase, G.; Traversa, A.; Montemurro, F.; Mastrangelo, M.; Fiore, A.; Ventrella, G.; Brunetti, G. Minimum tillage and organic fertilization for the sustainable management of Brassica carinata A. (Braun) in the Mediterranean environment. Environ. Sci. Pollut. Res. 2018, 25, 33556-33565. [CrossRef] [PubMed]

104. Abou Chehade, L.; Antichi, D.; Martelloni, L.; Frasconi, C.; Sbrana, M.; Mazzoncini, M.; Peruzzi, A. Evaluation of the agronomic performance of organic processing tomato as affected by different cover crop residues management. Agronomy 2019, 9, 504. [CrossRef]

105. Guidobono Cavalchini, A.; Rognoni, G.L.; Tangorra, F.M.; Costa, A. Experimental tests on winter cereal: Sod seeding compared to minimum tillage and traditional plowing. J. Agric. Eng. 2013, XLIV(s2), 392-396.

106. Marandola, D.; Marongiu, S. Più efficienza al Centro-Sud con la semina su Sodo. L'Informatore Agrario 2012, 40, 75-78.

107. Iezzi, G.; Roggero, P.P.; Santilocchi, R.; Seddaiu, G. Effects of repeated sod seeding or ntinimum tillage and nitrogen fertilisation on durum v,heal grain yield in the clay hills of central ltabt- pvss. In Proceedings of the VII European Society for Agronomy Congress, Cordoba, Spain, I5-18 July 2002; pp. 499-500.

108. Scopel, E.; Triomphe, B.; Affholder, F.; Macena, F.; Corbeels, M.; Xavier, J.; Lahmar, R.; Recous, S.; Bernoux, M.; Blanchart, E.; et al. Conservation agriculture cropping systems in temperate and tropical conditions, performances and impacts. A review. Agron. Sustain. Dev. 2013, 33, 113-130. [CrossRef]

109. Calcante, A.; Oberti, R. A Technical-Economic Comparison between Conventional Tillage and Conservative Techniques in Paddy-Rice Production Practice in Northern Italy. Agronomy 2019, 9, 886. [CrossRef] 